\title{
Detection of Coat Protein Gene of the Potato Leafroll Virus by Reverse Transcription Loop-Mediated Isothermal Amplification
}

\author{
Mohammad Amin Almasi ${ }^{1 *}$, Hossein Jafary ${ }^{2}$, Aboubakr Moradi $^{1}$, Neda Zand ${ }^{2}$, Mehdi Aghapour Ojaghkandi ${ }^{1}$ and Saeedeh Aghaei ${ }^{1}$ \\ ${ }^{1}$ Department of Plant Biotechnology, Faculty of Agriculture, University of Zanjan, Zanjan, Iran \\ ${ }^{2}$ Department of Plant Protection, Agricultural and Natural Resources Research Center of Zanjan, Zanjan, Iran
}

\begin{abstract}
Loop-mediated isothermal amplification assay amplifies DNA/RNA with high specificity and sensitivity. In this study, we describe an optimized reverse transcription- LAMP assay for detection of Potato Leafroll Virus. Firstly, DAS-ELISA assay was performed to detect of the virus in a collection containing 40 suspicious samples. Lastly, two samples were detected as the positive samples. Then, the positive samples were verified by RT-PCR and RT-LAMP methods. Furthermore, the results demonstrated that the RT-LAMP assay was 40 times sensitive and 4 time faster compared to RT-PCR. RT-LAMP assay was accomplished in the water bath either frees from any thermal cycler machine or sophisticated laboratories facility. Moreover, in RT-LAMP reaction the positive samples were detected through turbidity which produced by magnesium pyrophosphate. Interestingly, the application of $\mathrm{CaCl}_{2}$ instead of $\mathrm{MgSO}_{4}$ which create calcium pyrophosphate in reaction could significantly increase both stability and concentration of turbidity. Consequently, it could be an interesting alternative to MgSO4. Overall, the newly developed RT-LAMP assay can be a sensitive, specific and low-cost method for early detection of Potato Leafroll Virus and also other viral plant pathogens.
\end{abstract}

Keywords: Potato Leafroll virus; Coat protein gene; RT-LAMP; RTPCR

\section{Introduction}

Potato (Solanum tuberosum) is the fourth important food resources in the daily food chain which was affected by several pathogenic agents including viruses, resulting a significant diminution in yield production worldwide. Despite the presence of a broad spectrum of diverse deleterious viruses, the most common and economic ones are Potato virus A, Potato virus Y (PVA, PVY, both from genus Potyviruses), Potato leafroll virus (PLRV, genus Polerovirus), Potato virus $X$ (PVX, genus Potexvirus) and Potato virus $S$ (PVS, genus Carlavirus) [1-4]. Viruses of the family Luteoviridae belongs to ssRNA plant viruses, divided into three genera: Enamovirus, Luteovirus and Polerovirus [5]. Members of this family infect a broad range of mono- and dicotyledonous plants that they exclusively replicate in the phloem tissue [6]. PLRV infects potato plants, causing economic losses on the yield [7,8]. PLRV causes characteristic rolling of leaves, chlorosis and stunting of infected plants [9]. In a number of cultivars, PLRV also causes a dark discoloration of the tubers so-called "net necrosis" that refers to a selective death and damage of cells in the phloem tissue of tubers [10, 11]. Additionally, PLRV can be transmitted in a persistent manner by a limited number of aphid species [12]. Also, the two main vector aphids are the green peach aphid (Myzus persicae) and the potato aphid (Macrosiphum euphorbiae) [2,9]. PLRV has isometric capsids containing a singlestranded (ss) messenger-sense RNA (5.9 kb) molecule with several open reading frames (ORFs) linking to a small protein (VPg) $[13,14]$. Vegetative part of potato (the tubers) is used as planting materials in most countries; a tuber-borne PLRV infection can indefinitely propagate. Furthermore, one of the most important measures in favor of diseases management in potato fields is to use of the certified virusfree tuber as 'seed' for planting [15].

PLRV control measures are time-consuming and expensive. Thus, development of rapid and reliable diagnostic method(s) to detect virus-free tubers can be effective to control of pathogen. Typically, in the recent decades the molecular techniques have been applied for discrimination of viruses and other plant pathogens. In this regards, several molecular methods have been developed for detection of the PLRV, including nucleic acid sequence-based amplification (NASBA) [16], Northern blotting [7], immunecapture RT-PCR (IC-RT-PCR) [3], reverse transcription polymerase chain reaction (RT-PCR) [16-27], Multiplex AmpliDet RNA [18], and real-time RT-PCR [1,19]. Although those methods are sensitive and specific, they are either complicated or expensive. Alternatively, they need equipped laboratories and educated experts [8]. To address these limitations, isothermal-based detection methods such as loop-mediated isothermal amplification (LAMP) were developed. Some different form of this technique including RTLAMP and IC-RT-LAMP were universally used $[2,3,20,21]$. Briefly, the LAMP assay can specifically amplified DNA sequences by using a set of 4 primers, which recognize 6 distinct regions on the target DNA. Additionally, a pair of Loop primers (i.e., LF and LB) can accelerate LAMP reaction as well as reduce the time. In the LAMP reaction, nucleic acids amplify under isothermal conditions in a range of $60^{\circ} \mathrm{C}$ $-65^{\circ} \mathrm{C}$. Hence, it allows using of simple and cost effective equipments $[23,20,21]$. Up to now, numerous studies in both plants and animals have been reported to recognize pathogens by LAMP technique. For instance, RT-LAMP method were utilized for detection of Plasmodium falciparum gametocytes [9], Fusarium graminearum [23], Peste des petits ruminants virus (PPRV) [24], Potato virus Y (PVY) [10], Japanese yam mosaic potyvirus (JYMV) [22], Rabies virus (RABV) [19], Macrobrachium rosenbergii noda virus (MrNV) [25], Cymbidium

*Corresponding author: Mohammad Amin Almasi, Department of Plant Biotechnology, Faculty of Agriculture, University of Zanjan, Zanjan, Iran, E-mail: aminalmasi66@gmail.com

Received November 19, 2012; Accepted December 29, 2012; Published January 03, 2013

Citation: Almasi MA, Jafary H, Moradi A, Zand N, Ojaghkandi MA, et al (2013) Detection of Coat Protein Gene of the Potato Leafroll Virus by Reverse Transcription Loop-Mediated Isothermal Amplification. J Plant Pathol Microb 4:156. doi:10.4172/2157-7471.1000156

Copyright: (c) 2013 Almasi MA, et al. This is an open-access article distributed under the terms of the Creative Commons Attribution License, which permits unrestricted use, distribution, and reproduction in any medium, provided the original author and source are credited. 
mosaic virus (CymMV) [26] and Potato Leafroll Virus (PLRV) [2,3]. As described earlier, some different visualizing systems are employed for verification of LAMP products. Among these, utilization of $\mathrm{MgSO}_{4}$ which produces magnesium pyrophosphate (white precipitate) in positive sample considered a simple, cost-effective and safe verification approach [27]. Unfortunately, the turbidity is unstable and after a few seconds vanishes. To improve such shortcomings, the application of $\mathrm{MgCl}_{2}$ instead of $\mathrm{MgSO}_{4}$ was suggested but, no significant achievement was observed [10].

The aim of this study, were to develop and optimize a sensitive and specific RT-LAMP assay for detection of PLRV based on a new visualizing system by using $\mathrm{CaCl}_{2}$ instead of $\mathrm{MgSO}_{4}$ in order to increase both stability and concentration of turbidity.

\section{Materials and Methods}

\section{Viruses samples and DAS-ELISA assay}

Forty suspicious potato leaf samples which showed symptoms of infection with PLRV were collected from some potato fields (Zanjan, Iran). The presence of the virus in the whole collection was first confirmed via DAS-ELISA assay by polyclonal PLRV specific antibodies (IgG: AS-110612, RAM AP: AS-110621, Bioreba AG). DAS-ELISA was carried out according to previous protocols with some minor modifications, firstly, using a commercial PLRV IgG and the alkaline phosphatase-conjugated PLRV IgG [28]. Polystyrene microtiter plates were coated for $3 \mathrm{~h}$ at $34^{\circ} \mathrm{C}$, with $200 \mu \mathrm{l}$ per well of IgG coating, in $50 \mathrm{mM}$ carbonate buffer ( $\mathrm{pH}$ 9.6). Then, the plates were incubated for $1 \mathrm{~h}$ at $34^{\circ} \mathrm{C}$ with $\mathrm{PBS}(10 \mathrm{mM}$ phosphate buffer $\mathrm{pH} 7.2,0.8 \% \mathrm{NaCl}$ and $0.02 \% \mathrm{KCl})$. Afterwards, the plates were washed three times, with washing buffer $(0.8 \% \mathrm{NaCl}, \mathrm{pH} 7.2$ and $0.05 \%$ Tween 20$)$. The infection free (control) and PLRV-infected potato leaf samples were ground in 10 volumes $(\mathrm{w} / \mathrm{v})$ of PBS buffer $(\mathrm{pH} 7.2)$, containing $0.2 \%$ polyvinyl pyrolidone (PVP) and 2\% of egg albumin (Sigma A5253).The infected preparations were serially diluted (five-fold dilution) at the same buffer. Next, aliquots of $195 \mu \mathrm{l}$ of prepared samples were added to each well, followed by incubation at $4^{\circ} \mathrm{C}$ overnight. Plates were then washed three times by washing buffer and incubated for $4 \mathrm{~h}$ at $37^{\circ} \mathrm{C}$, with 190 $\mu \mathrm{l}$ per well of alkaline phosphatase-conjugated PLRV IgG diluted in sample buffer and washed again. Finally, it incubated for $90 \mathrm{~min}$, with p-nitrophenylphosphate $(1 \mathrm{mg} / \mathrm{ml})$, in $10 \%$ diethanolamine $\mathrm{pH} 9.8$.

\section{RNA extraction}

RNA was purified from PLRV-infected potato leaves according to former protocol [29]. $2 \mathrm{ml}$ of extraction buffer $\left(21.7 \mathrm{~g} \mathrm{~K}_{2} \mathrm{HPO}_{4} .3 \mathrm{H}_{2} \mathrm{O}\right.$, $1.4 \mathrm{~g} \mathrm{KH}_{2} \mathrm{PO}_{4}$, $\mathrm{pH}$ 7.4, $100 \mathrm{~g}$ sucrose, $1.5 \mathrm{~g} \mathrm{BSA}, 20 \mathrm{~g}$ PVP, and $5.3 \mathrm{~g}$ ascorbic acid) was transferred into a mortar containing $0.2 \mathrm{~g}$ of leave samples. Next, two successive centrifugations were performed, $10 \mathrm{~min}$ $(1100 \mathrm{~g})$ and $20 \mathrm{~min}(16800 \mathrm{~g})$ at $4^{\circ} \mathrm{C}$, respectively. Then, the resultant precipitate was mixed with $0.2 \mathrm{ml}$ TE buffer (10 mM EDTA, $50 \mathrm{mM}$ Tris- $\mathrm{HCl}, \mathrm{pH} 8,0.1 \%$ mercaptoethanol) and 10\% Sodium Dodecyl Sulphate (SDS). Afterwards, $80 \mu \mathrm{l}$ of $5 \mathrm{M}$ acetate potassium was added and the solution incubated for $10 \mathrm{~min}$ at $60^{\circ} \mathrm{C}$ and for overnight at $4^{\circ} \mathrm{C}$, respectively. Then, the tubes were centrifuged at $4^{\circ} \mathrm{C}$ for $15 \min (16800$ g). The aqueous phase was harvested and $30 \mu \mathrm{l}$ acetate sodium $3 \mathrm{M}$ was added followed by isopropanol. After incubation at $-20^{\circ} \mathrm{C}$ for $2 \mathrm{~h}$, the last centrifugation was performed at $4^{\circ} \mathrm{C}$ for $20 \mathrm{~min}(16800 \mathrm{~g})$. The resultant pellet was washed with $70 \%$ ethanol, dried under a vacuum, and dissolved in a total volume of $15 \mu \mathrm{l}$ of double distilled water.

\section{cDNA preparation and $\mathrm{RT}$-PCR reaction}

Extracted RNA $(5 \mu \mathrm{l})$ was incubated at $75^{\circ} \mathrm{C}$ for $3 \mathrm{~min}$ and chilled on ice for $3 \mathrm{~min}$. Then, 20 pmol backward primer, $50 \mathrm{mM}$ Tris-HCL, $\mathrm{pH} 8.3,10 \mathrm{mM}$ dithiothreithol (DTT), $2.5 \mathrm{mM} \mathrm{MgCl}, 10 \mathrm{mM}$ of each dNTP (dATP, dTTP, dCTP and dGTP), $5 \mathrm{U}$ of RNasin Ribonuclease Inhibitor (Fermentas Co, Cat. No EO0381), and $100 \mathrm{U}$ of Moloney murine leukemia virus (M-MLV) reverse transcriptase (Fermentas Co, Cat. No EP0351) were added to RNA. Afterwards, mixtures were incubated at $45^{\circ} \mathrm{C}$ for $45 \mathrm{~min}$. lastly; the obtained cDNA was used as template for PCR or two-step RT-LAMP. RT-PCR was performed by using specific primers which were designed based on CP gene [29]. Performing, on a Thermal Cycler (iCycler, BIO RAD, CA, USA) in a 25 $\mu$ volume containing $1 X$ PCR buffer (10 mM Tris-HCL, $\mathrm{pH} 8.3,50 \mathrm{mM}$ $\mathrm{KCl}), 1.5 \mathrm{mM} \mathrm{MgCl}, 0.2 \mathrm{mM}$ of each dNTP, $20 \mathrm{pmol}$ of each forward and backward primers, $0.625 \mathrm{U}$ of Taq DNA polymerase (Cinagen Co, Cat. No TA7505C) and $2 \mu \mathrm{l}$ cDNA. Subsequently, mastermix were amplified at $94^{\circ} \mathrm{C}$ for $3 \mathrm{~min}$, for 35 cycles followed by for $1 \mathrm{~min}$ at $94^{\circ} \mathrm{C}$, $1 \mathrm{~min}$ at $54^{\circ} \mathrm{C}$ and $1 \mathrm{~min}$ at $72^{\circ} \mathrm{C}$. A final extension was accomplished for $10 \mathrm{~min}$ at $72^{\circ} \mathrm{C}$. Finally, amplified products $(5 \mu \mathrm{l})$ were loaded on a $1.5 \%$ agarose gel containing ethidium bromide, eventually visualized under UV illuminator.

\section{Developing of primers for LAMP}

The complete genome sequence of PLRV is available at Gen bank (accession no. U73777.1). The specific LAMP primers were designed based on conserved sequence (ORF3) of CP gene by using the Primer Explorer V4 software (http://primerexplorer.jp/e/) and primers including Outer primers (F3 and B3) and Inner primers (FIP and BIP). Moreover, In order to accelerate as well as to reduce the time of LAMP reaction, an additional Loop primers (LF and LB) were developed (Table 1). In addition, figure 1 shows the position of the RT-LAMP primers on ORF3.

\section{Two-step RT-LAMP}

Two-step RT-LAMP was carried out by using obtained cDNA which was previously described. cDNA $(3 \mu \mathrm{l}$ at $10 \mathrm{ng} / \mu \mathrm{l})$ was incubated at $95^{\circ} \mathrm{C}$ for $5 \mathrm{~min}$ and chilled on ice and it was served as a template in

\begin{tabular}{|l|l|l|l|l|l|}
\hline Primer & Type & Position on gene & Length of primer & Length of product & Sequence(5'-3') \\
\hline Forward & Forward outer & $85-104$ & $20 \mathrm{nt}$ & $336 \mathrm{bp}$ & CGCGCTAACAGAGTTCAGCC \\
\hline Backward & Backward outer & $420-401$ & $20 \mathrm{nt}$ & & GCAATGGGGGTCCAACTCAT \\
\hline F3 & Forward outer & $61-78$ & $18 \mathrm{nt}$ & AGAAGGCAATCCCTTCGC \\
\hline B3 & Backward outer & $245-264$ & $20 \mathrm{nt}$ & GGTGAAACTTCCTTGGGTGT \\
\hline FIP & Forward inner & $139-159$ and 79-96 & $43 \mathrm{nt}$ & GCCTCCTCTTCTGCGTCTTCGTTTTAGGCGCGCTAACAGAGTT \\
\hline BIP & Backward inner & $161-182$ and 223-241 & $45 \mathrm{nt}$ & ATCGCCGCTCAAGAAGAACTGGTTTTCCACGAGGTTGTCCTTTGT \\
\hline LF & Loop forward outer & $97-118$ & $22 \mathrm{nt}$ & CCGTGACCATAACCACTGGCTG \\
\hline LB & Loop backward outer & $191-210$ & $20 \mathrm{nt}$ & GAGGACGAGGCTCAAGCGAG \\
\hline
\end{tabular}

Table 1: Oligonucleotide primers used for RT-LAMP and RT-PCR of coat protein gene of PLRV. RT-PCR primers (forward and backward) were designed by Oligo7 software that amplifies a 336 bp fragment. RT-LAMP primers (F3, B3, FIP, BIP, LF and LB) were designed by PrimerExplorer V.3 that produced many fragments with different sizes from which the smallest fragment was $163 \mathrm{bp}$ in size. 


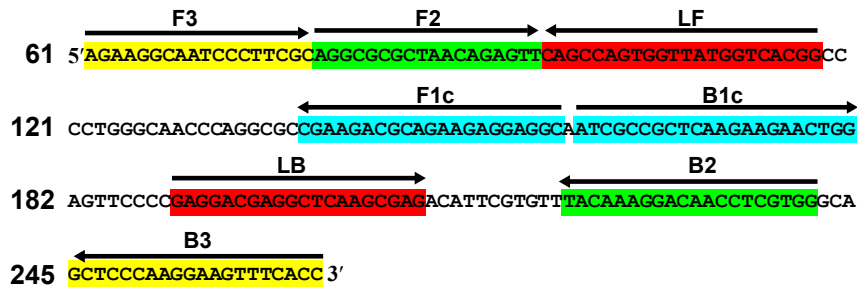

Figure 1: Position of the Oligonucleotide primers used for RT-LAMP on coat protein gene of PLRV.

LAMP reaction. The LAMP mixture containing $20 \mathrm{mM}$ Tris- $\mathrm{HCl}, \mathrm{pH}$ 8.8, $10 \mathrm{mM} \mathrm{KCl}, 10 \mathrm{mM}\left(\mathrm{NH}_{4}\right)_{2} \mathrm{SO}_{4}, 0.1 \%$ Triton X-100, $2 \mathrm{mM}$ Betaine (Sigma-Aldrich, Oakville, Ontario, Canada), $1 \mathrm{mM} \mathrm{MgSO}_{4}, 10 \mathrm{mM}$ of each dNTP, $0.2 \mu \mathrm{M}$ each of F3 and B3, $0.8 \mu \mathrm{M}$ each of FIP and BIP, 0.6 $\mu \mathrm{M}$ each of LF and LB, and $8 \mathrm{U}$ of Bst DNA polymerase (New England Biolabs Inc.). The mixture was incubated at $62^{\circ} \mathrm{C}$ for $1 \mathrm{~h}$, followed by $5 \mathrm{~min}$ at $80^{\circ} \mathrm{C}$ to terminate of reaction in a water bath. Finally, LAMP products $(5 \mu \mathrm{l})$ were visualized by naked eye and also analyzed by electrophoresis as described earlier.

\section{One-step RT-LAMP}

This reaction was performed in $25 \mu$ l volume by using RNA as a template. The reaction mixture contained $5 \mu \mathrm{l}$ of RNA, $100 \mathrm{U}$ of M-MLV reverse transcriptase, RNasin Ribonuclease Inhibitor (5 U) and $10 \mathrm{mM}$ DTT. The RNA was incubated at $75^{\circ} \mathrm{C}$ for $3 \mathrm{~min}$ and chilled on ice. Then, the denatured RNA solution was added to the RT-LAMP mixture. Thereafter, the solution was incubated at $45^{\circ} \mathrm{C}$ for $45 \mathrm{~min}$ and then $62^{\circ} \mathrm{C}$ for $1 \mathrm{~h}$, followed by $5 \mathrm{~min}$ at $80^{\circ} \mathrm{C}$ in a water bath. Finally, the products were analyzed by gel electrophoresis.

\section{Real-time RT-LAMP}

In this study, real-time RT-LAMP assay was performed for precise detection of PLRV by using fluorescence which was derived from SYBR ${ }^{\circledR}$ Premix Ex Taq ${ }^{\mathrm{TM}}$ II that it can be bind to the dsDNA. Consequently, it was measured by real-time thermal cycler (Roto Gene CR6000). Fluorescence-intercalation dye (SYBR ${ }^{\circledR}$ Premix Ex Taq $\left.{ }^{\mathrm{TM}} \mathrm{II}\right)$ based real-time RT-LAMP (FRt-RT-LAMP) was carried out with and without $\mathrm{LF}$ and LB primers. $3 \mu \mathrm{l} \mathrm{cDNA}$ was considered as a template. Furthermore, $0.8 \mu \mathrm{M}$ SYBR $^{\circledR}$ Premix Ex Taq ${ }^{\mathrm{TM}}$ II (Perfect Real TIME, TAKARA Bio Co, LTD, RR081A) was added to $22 \mu$ l of LAMP mixture. The mixture was placed on a real time thermal cycler at $62^{\circ} \mathrm{C}$ for $1 \mathrm{~h}$.

\section{Optimization of $\mathrm{CaCl}_{2}$}

In the LAMP reaction when DNA polymerizes, producing pyrophosphate ions and interaction between pyrophosphate and magnesium lead to produce magnesium pyrophosphate (white precipitate) which can be observed and detectable as turbidity in positive samples. In contrast, negative control remains transparent without any turbidity [27]. Use of $\mathrm{MgCl}_{2}$ or $\mathrm{MgSO}_{4}$ in LAMP reaction in order to create turbidity has some drawbacks such as, low stability and concentration. In this research, we used $\mathrm{CaCl}_{2}$ to address these disadvantages. Thus, different dilutions of $\mathrm{CaCl}_{2}(0.01 \mathrm{mM}$ to $0.5 \mathrm{mM})$ were examined to improve both stability and concentration of turbidity in LAMP reaction.

\section{Results}

\section{DAS-ELISA and RT-PCR reaction}

DAS-ELISA assay could successfully detect two (5\%) positive sample among 40 natural samples. Remarkably, changes in the color of the infected samples in wells were much clear, so that there was no need for ELISA Reader (Figure 2a). The positive samples were nominated as PLRV10 and PLRV16 and ultimately, they used for further analyses. Additionally, the positive samples were detected by RT-PCR assay and a predictable fragment (336 bp) was observed on agarose gel (Figure $2 b)$.

\section{Optimization of LAMP reaction}

The effects of temperatures and times as well as the concentrations of dNTP, cDNA, primers, Bst DNA polymerase, Betaine and $\mathrm{MgSO}_{4}$ were examined. Temperatures range was considered between 45 $-75^{\circ} \mathrm{C}$. The results showed that the amplification occurred at $55^{\circ} \mathrm{C}$, $60^{\circ} \mathrm{C}, 63^{\circ} \mathrm{C}$ and $65^{\circ} \mathrm{C}$ (Figure 3a). Moreover, the minimum time for completion of reaction was $30 \mathrm{~min}$ (Figure $3 \mathrm{~b}$ ). To test the effects of dNTPs concentration on RT-LAMP reaction, final concentration of 0.2 to $10 \mathrm{mM}$ was prepared. The results showed that at $5 \mathrm{mM}$ and 10 $\mathrm{mM}$, ladder-like DNA fragments were clearly observed (Figure 4a).

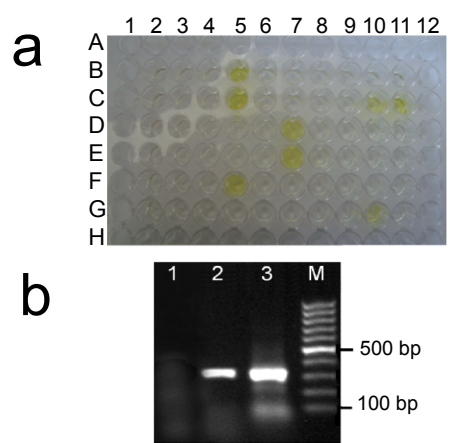

Figure 2: a) the results of DAS-ELISA assay for PLRV. The positive control (5F and 10C), PLRV10 (5B, 5C and 11C) and PLRV16 (7D, 7E and 10G) are shown in green. b) Electrophoresis of the RT-PCR product on $1.5 \%$ agarose gel visualized by Ethidium Bromide staining under UV illumination. The RT-PCR reaction was carried out using PLRV specific primers and amplified a $336 \mathrm{bp}$ fragment. Lanes: 1, water control; 2 PLRV10; 3 PLRV16; M, 100 bp ladder.
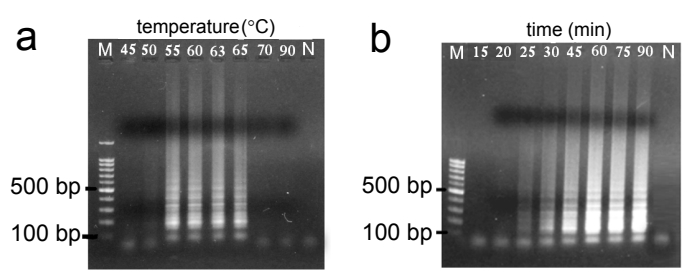

Figure 3: Optimization of RT-LAMP reaction for detecting of PLRV: a) Effects of temperature; The optimized temperature was $65^{\circ} \mathrm{C}$; b) Effects of the reaction time ; the optimized reaction time was 60 min. Lanes: M, 100 bp ladder; N, water control.
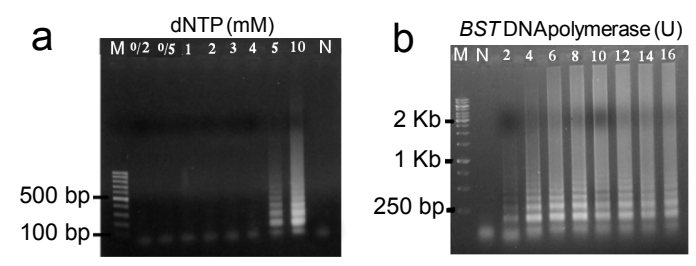

Figure 4: Optimization of RT-LAMP reaction for detecting of PLRV: a) Effects of dNTPs concentration; $10 \mathrm{mM}$ was selected as the optimized concentration; b) Effects of Bst DNA polymerase concentrations; $8 \mathrm{U}$ of enzyme was selected as optimized concentration. Lanes: M, 100 bp ladder; N, water control. 
Different concentrations (2 $\mathrm{U}$ to $16 \mathrm{U}$ ) of Bst DNA polymerase were used to select the minimum concentrations with the good performance. With low concentration of the enzyme (2U), poor amplification of DNA was observed, but with increasing of the enzyme concentration to $4 \mathrm{U}$ or $8 \mathrm{U}$, the amplification considerably improved (Figure $4 \mathrm{~b}$ ). In order to optimize the concentration of primers the outer primers (B3 and F3), inner primers (FIP and BIP), and loop primers (LF and LB) were used with 5 to 50 pmol. The results demonstrated that 10 , 20 and 20 pmol were selected for outer, inner, and loop primers, respectively (Figure 5a). A Betaine concentration from $0.2 \mathrm{mM}$ to 250 $\mathrm{mM}$ was examined. When the concentration of Betaine increased from 0.2 to $100 \mathrm{mM}$, the intensity of the amplified products increased but, no visible products were detected when the concentration increased to $250 \mathrm{mM}$. Different concentrations $(0.2$ to $250 \mathrm{mM})$ of $\mathrm{MgSO}_{4}$ were inspected and results showed that at the 0.2 to $1 \mathrm{mM}$ of $\mathrm{MgSO}_{4}$ concentrations amplification were observed while at 5 to $250 \mathrm{mM}$ there were no visible products (Figure $5 \mathrm{~b}$ ). Due to drawbacks of $\mathrm{MgCl}_{2}$ (low stability and concentration). In this study, $\mathrm{CaCl}_{2}$ was employed to achieve significant improvement in both stability and concentration of turbidity. The results showed that at $10 \mathrm{mM} \mathrm{CaCl}_{2}$ concentration the best quality was observed. Moreover, it is noticeable that, even though the $20 \mathrm{mM}$ created positive results, the resolution of the bands were a little low than $10 \mathrm{mM}$ (Figure 6)
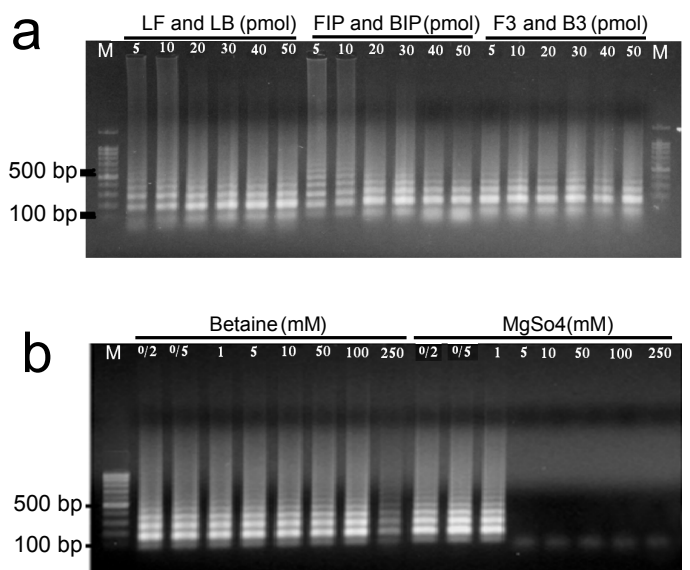

Figure 5: Optimization of RT-LAMP reaction for detecting of PLRV: a) Effects of primer concentrations; 5 pmol concentrations for $\mathrm{F} 3$ and $\mathrm{B} 3$ primers, and 20 pmol for LF, LB, FIP and BIP were selected as optimized concentration of primers; b) Effects of Betaine and $\mathrm{MgSO}_{4}$ concentrations; $100 \mathrm{mM}$ concentration for Betaine and $1 \mathrm{mM}$ concentration for $\mathrm{MgSO}_{4}$ were selected as optimized concentrations. Lanes: M, 100 bp ladder.

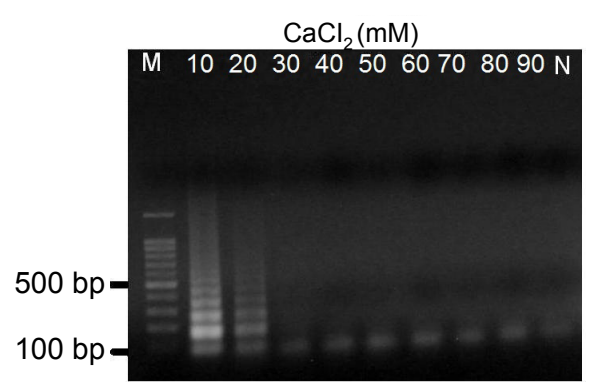

Figure 6: Effects of $\mathrm{CaCl}_{2}$ and cDNA concentrations. $0.01 \mathrm{mM} \mathrm{CaCl}$ concentrations were selected as optimized concentrations. Lanes: M, 100 bp ladder; N, water control. a

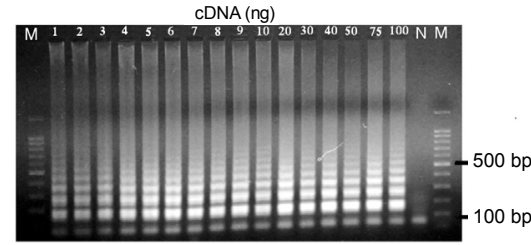

$\mathrm{cDNA}(\mathrm{ng})$

b

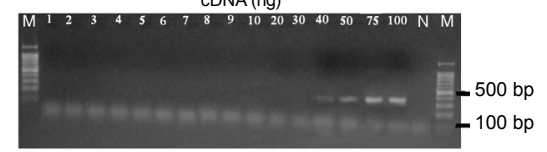

Figure 7: The results of sensitivity for PLRV: a) Amplification was observed in 1 $\mathrm{ng} / \mathrm{\mu l}$ concentration of cDNA for RT-LAMP; b) Amplification was observed in 40 $\mathrm{ng} / \mathrm{\mu l}$ concentration of cDNA for RT-PCR respectively. Lanes: M, 100 bp ladder; $\mathrm{N}$, water control. a

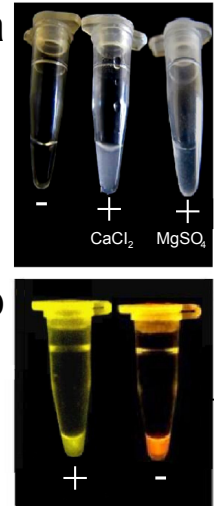

C

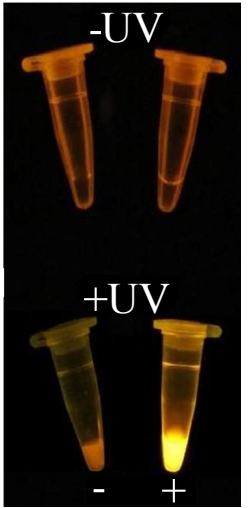

Figure 8: Visual detection of positive RT-LAMP reaction: a) Visible precipitate due to the formation of magnesium pyrophosphate and Calcium pyrophosphate with naked-eye; b) Using SYBR Green dyes under UV illumination; c) Using Ethidium Bromide under UV illumination.

\section{Sensitivity of the RT-LAMP assay}

To determine the sensitivity of RT-LAMP reaction different concentrations of cDNA ( $1 \mathrm{ng} / \mu \mathrm{l}$ up to $100 \mathrm{ng}$ ) were tested. The results indicated that even with $1 \mathrm{ng} / \mu \mathrm{l}$ of cDNA amplification perfectly worked while RT-PCR reaction was completed with a minimum of 40 $\mathrm{ng} / \mu \mathrm{l}$ of cDNA. The all products (per each $5 \mu \mathrm{l}$ ) were analyzed on $1.5 \%$ agarose gel (Figures $7 \mathrm{a}$ and $\mathrm{b})$.

\section{Visual detection of RT-LAMP products and Real-time RT- LAMP}

Positive reactions were accompanied with cloudy phase due to the formation of magnesium pyrophosphate and calcium pyrophosphate (Figure 8a). In addition, $2 \mu \mathrm{SYBR}^{\circledR}$ Premix Ex Taq ${ }^{\mathrm{TM}}$ II (Perfect Real TIME, TAKARA Bio Co, LTD, RR081A) was added to $25 \mu \mathrm{l}$ RTLAMP product under UV illumination $(302 \mathrm{~nm})$; the positive reaction appeared in green color (Figure $8 \mathrm{~b}$ ). Also, positive reaction was visualized by using Ethidium bromide under UV illumination, adding $0.5 \mu \mathrm{l}$ of the diluted ethidium bromide turned colour of the positive sample in to ocherish yellow (Figure 8c).

Fluorescence-intercalation dye $\left(\mathrm{SYBR}^{\circledR}\right.$ Premix Ex TaqTM II)based real time RT-LAMP (FRt-RT-LAMP) was carried out with LF and LB and without those primers. The results demonstrated that in the presence of the loop primers the amplification began at 15 min while under the absence of loop primers, amplification started at $44 \mathrm{~min}$ 


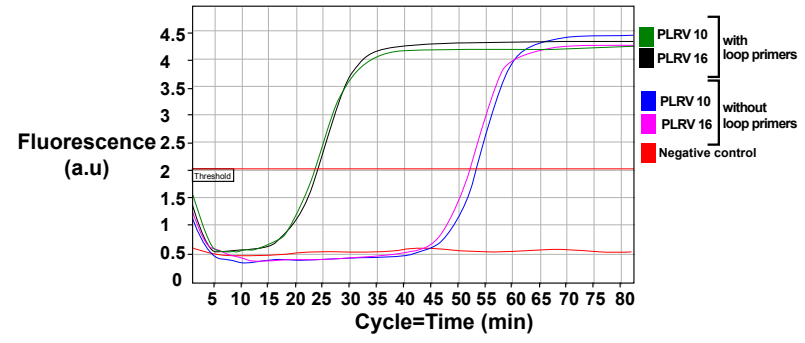

Figure 9: Fluorescence-intercalation dye (SYBR ${ }^{\circledR}$ Premix Ex $\operatorname{Taq}^{\mathrm{TM}}$ II)-based real time RT-LAMP (FRt-RT-LAMP), with and without using loop primers. The amplification started by 15 min using the loop primers and by 44 min without loop primers.

(Figure 9). Therefore, using loop primers would speed up the reaction in real- time RT-LAMP assays.

\section{Discussion}

Potato is a vulnerable host for abundant viral infectious agents. In crops in which true seeds are used for propagation, most of the time, flower works as a powerful barrier against transmission of viruses to the seeds of the next generation. While in potato fields, the true seeds are rarely used and the tubers are mainly used for propagating. Therefore, for viral pathogens is quite straightforward way to infect host plants to the new-formed tubers. Since there is no effective viricide to control of the viruses in potato, using virus free seed potatoes is an effective approach for management of potato viral disease. In Iranian seed potato market, along with other part of the world, demands for certified potato seed tubers are increasing $[2-3,30]$. In order to produce infection free potato seed tubers, using rapid, cost-effective and sensitive methods for detection of important potato viruses, including PLRV, in different stages of infection process would provide a great step forward. Various experimental methods have already been utilized for detecting of PLRV as well as other important viral agents in potato from which DNA/RNA-based methods are now considered among most important detection methods. The RT-LAMP assay is one of those nucleic acidbased methods that were introduced by beginning of $21^{\text {st }}$ century. This method was first applied for detecting of human and animal pathogens. It is not for a long time that this technique is being used in plant pathology. However, the number of plant pathogens that have been detected with this technique in the last few years is remarkably increased. For several reasons we encourage potato pathologists and potato seed inspectors to use of this method for detecting of PLRV.

\section{It is safe and easy method to work with}

The amplification products of RT-LAMP reaction, which are stemloop DNA structure with several inverted repeats and cauliflower-like structure with multiple loops, can be monitored visually and therefore using of toxic staining materials can be avoided [22]. This would simplify the detection procedure and would result in saving of significant time which is needed for separating of the amplified products on the gel and the analyzing of the data which is commonly used in other PCR-based methods.

\section{It is a technician friendly method}

The isothermal conditions required by RT-LAMP could be met easily using a water bath or a temperature block, whereas the rapid and accurate temperature change required by other nucleic acid-based methods including RT-PCR.

\section{It is a rapid and a highly specific method}

The higher specificity and sensitivity of this method has already been compared with other nucleic acid-based methods such as RT-PCR $[8,31]$. The results of the present study showed that the LAMP reaction can be completed within 30-40 min with about $1 \mathrm{ng} / \mu \mathrm{l}$ of cDNA, while RT-PCR needed at the least 3 hours with $40 \mathrm{ng} / \mu \mathrm{l}$ of cDNA to complete a reaction. One may conclude that RT-LAMP works faster (4-fold) with higher sensitivity (40-fold) for detecting of PLRV compared with RT-PCR. These results parallel with previous studies, suggesting that RT-LAMP can be 10 to 100 -fold more sensitive than RT-PCR [24,32-34]. Overall, our results showed that some ingredients of RTLAMP reaction, such as $\mathrm{MgSO}_{4}$, Betaine, primers, dNTPs, and DNA polymerase concentrations, as well as temperature and time period of the reaction play important roles in efficiency of the assay. At the end of the reaction, the infected samples can be easily visualized with naked eye. However, the turbidity of the positive samples is not stable for a longer time and it should be judged soon after taking out of the samples from the water bath or from the thermal cycler. As a solution, adding SYBR Green and Ethidium Bromide to the tubes will provide enough time to monitor changes in the color of the tubes and to detect the positive samples under UV illumination as stressed by other workers $[25,33]$. However, using of toxic staining materials and UV irradiation would not be compatible with the main feature of this technique which is "safety". It seems that using of some other alternative chemicals to stabilize the turbidity of positive samples for a longer time would increase the efficiency of this method. Interestingly, our results showed that the application of $\mathrm{CaCl}_{2}$ can accompany with more reliable outputs than $\mathrm{MgSO}_{4}$ when both stability and concentration of the turbidity are taken into account. Consequently, $\mathrm{CaCl}_{2}$ can be proposed as the best alternative options for $\mathrm{MgSO}_{4}$ to enhance the stability and also to avoid applying toxic materials.

In conclusion, the RT-LAMP method was successfully developed for rapid and sensitive detection of PLRV. Furthermore, it was approximately 40 times more sensitive compared to RT-PCR. The RT-LAMP assay did not require costly or sophisticated equipment and also use of $\mathrm{CaCl}_{2}$ instead of $\mathrm{MgSO}_{4}$ create significant turbidity which may be make RT-LAMP methodology safe, cost-effective and portable diagnostic tool for assessment of distribution of pathogen in the field. Additionally, this technique can be applied for routine screening of pathogens in large samples in epidemiological and pathological programs. Undoubtedly, RT-LAMP characteristics turn it in to a suitable alternative to ELISA and RT-PCR methods in order to accelerate decision-making processes in potato disease-management.

\section{Acknowledgments}

This work was financially supported by Agricultural and Natural Resources Research Center of Zanjan Province.

\section{References}

1. Agindotan BO, Shiel PJ, Berger PH (2007) Simultaneous detection of potato viruses, PLRV, PVA, PVX and PVY from dormant potato tubers by TaqMan real-time RT-PCR. J Virol Methods 142: 1-9.

2. Ahmadi S, Almasi MA, Fatehi F, Struik PC, Moradi A (2012) Visual Detection of Potato leafroll virus by One-step Reverse Transcription Loop-Mediated Isothermal Amplification of DNA with Hydroxynaphthol Blue Dye. J Phytopathol

3. Almasi MA, Moradi A, Nasiri J, Karami S, Nasiri M (2012) Assessment of Performance Ability of Three Diagnostic Methods for Detection of Potato Leafroll Virus (PLRV) Using Different Visualizing Systems. Appl Biochem Biotechnol 168: 770-784.

4. Mortimer-Jones SM, Jones MG, Jones RA, Thomson G, Dwyer GI (2009) A 
single tube, quantitative real-time RT-PCR assay that detects four potato viruses simultaneously. J Virol Methods 161: 289-296.

5. Terradot L, Souchet M, Tran V, Giblot Ducray-Bourdin D (2001) Analysis of a Three-Dimensional Structure of Potato leafroll virus Coat Protein Obtained by Homology Modeling. Virolology 286: 72-82.

6. van den Heuvel JF, Verbeek M, van der Wilk F (1994) Endosymbiotic bacteria associated with circulative transmission of potato leafroll virus by Myzus persicae. J Gen Virol 75: 2559-2565.

7. Gildow FE, Reavy B, Mayo MA, Duncan GH, Woodford JA, et al. (2000) Aphid Acquisition and Cellular Transport of Potato leafroll virus-like Particles Lacking P5 Readthrough Protein. Phytopathology 90: 1153-1161.

8. Goto M, Shimada K, Sato A, Takahashi E, Fukasawa T, et al. (2010) Rapid detection of Pseudomonas aeruginosa in mouse feces by colorimetric loopmediated isothermal amplification. J Microbiol Methods 81: 247-252.

9. Alvarez JM, Srinivasan R (2005) Evaluation of Hairy Nightshade as an Inoculum Source for Aphid-Mediated Transmission of Potato Leafroll Virus. J Econ Entomol 98: 1101-1108.

10. Nie X (2006) Reverse Transcription Loop-Mediated Isothermal Amplification of DNA for Detection of Potato virus Y. Plant Dis 89: 605-610.

11. Thomas PE, Lawson EC, Zalewski JC, Reed GL, Kaniewski WK (2000) Extreme resistance to Potato leafroll virus in potato cv. Russet Burbank mediated by the viral replicase gene. Virus Res 71: 49-62.

12. Guyader S, Ducray DG (2002) Sequence analysis of Potato leafroll virus isolates reveals genetic stability, major evolutionary events and differential selection pressure between overlapping reading frame products. J Gen Viro 83: 1799-1807.

13. van der Wilk F, Huisman MJ, Cornelissen BJ, Huttinga H, Goldbach R (1989) Nucleotide sequence and organization of potato leafroll virus genomic RNA FEBS Lett 245: 51-56.

14. van der Wilk F, Verbeek M, Dullemans AM, van den Heuvel JF (1997) The Genome-Linked Protein of Potato Leafroll Virus Is Located Downstream of the Putative Protease Domain of the ORF1 Product. Virology 234: 300-303.

15. Singh RP (1999) A solvent-free, rapid and simple virus RNA-release method for potato leafroll virus detection in aphids and plants by reverse transcription polymerase chain reaction. J Virol Methods 83: 27-33.

16. Leone G, van Schijndel HB, van Gemen B, Schoen CD (1997) Direct detection of potato leafroll virus in potato tubers by immunocapture and the isothermal nucleic acid amplification method NASBA. J Virol Methods 66: 19-27.

17. Singh RP, Kurz J, Boiteau G, Bernard G (1995) Detection of potato leafroll virus in single aphids by the reverse transcription polymerase chain reaction and its potential epidemiological application. J Virol Methods 55: 133-143.

18. Klerks MM, Leone GO, Verbeek M, van den Heuvel JF, Schoen CD (2001) Development of a multiplex AmpliDet RNA for the simultaneous detection of Potato leafroll virus and Potato virus $Y$ in potato tubers. J Virol Methods 93 : 115-125

19. Saitou Y, Kobayashi Y, Hirano S, Mochizuki N, Itou T, et al. (2010) A method for simultaneous detection and identification of Brazilian dog- and vampire bat-related rabies virus by reverse transcription loop-mediated isothermal amplification assay. J Virol Methods 168: 13-17.

20. Nagamine K, Hase T, Notomi T (2002) Accelerated reaction by loop-mediated isothermal amplification using loop primers. Mol Cell Probes 16: 223-229.

21. Notomi T, Okayama H, Masubuchi H, Yonekawa T, Watanabe K, et al. (2000) Loop-mediated isothermal amplification of DNA. Nucl Acids Res 28: e63.

22. Fukuta S, lida T, Mizukami Y, Ishida A, Ueda J, et al. (2003) Detection of Japanese yam mosaic virus by RT-LAMP. Arch Virol 148: 1713-1720.
23. Niessen L, Vogel RF (2010) Detection of Fusarium graminearum DNA using a loop-mediated isothermal amplification (LAMP) assay. Int J Food Microbiol 140: 183-191.

24. Li L, Bao J, Wu X, Wang Z, Wang J, et al. (2010) Rapid detection of peste des petits ruminants virus by a reverse transcription loop-mediated isothermal amplification assay. J Virol Methods 170: 37-41.

25. Haridas DV, Pillai D, Manojkumar B, Nair CM, Sherief PM (2010) Optimisation of reverse transcriptase loop-mediated isothermal amplification assay for rapid detection of Macrobrachium rosenbergii noda virus and extra small virus in Macrobrachium rosenbergii. J Virol Methods 167: 61-67.

26. Lee MS, Yang MJ, Hseu YC, Lai GH, Chang WT, et al. (2011) One-step reverse transcription loop-mediated isothermal amplification assay for rapid detection of Cymbidium mosaic virus. J Virol Methods 173: 43-48.

27. Mori Y, Nagamine K, Tomita N, Notomi T (2001) Detection of loop-mediated isothermal amplification reaction by turbidity derived from magnesium pyrophosphate formation. Biochem Biophys Res Commun 289: 150-154.

28. Clark MF, Adams AN (1977) Characteristics of the Microplate Method of Enzyme-Linked Immunosorbent Assay for the Detection of Plant Viruses. J Gen Virol 34: 475-483.

29. Rowhani A, Stace-Smith R (1979) Purification and Characterization of Potato Leafroll Virus. Virology 98: 45-54.

30. KH Ahouee, MK Habibi, GH Mosahebi H (2010) Detection of potato leafrol virus isolated from potato fields in Tehran province in aphids by immunocapture reverse transcription polymerase chain reaction. Afr J Biotechnol 9: 2349-2352.

31. Buates S, Bantuchai S, Sattabongkot J, Han ET, Tsuboi T, et al. (2010) Development of a reverse transcription-loop-mediated isothermal amplification (RT-LAMP) for clinical detection of Plasmodium falciparum gametocytes Parasitol Int 59: 414-420.

32. Pillai D, Bonami JR, Sri Widada J (2006) Rapid detection of Macrobrachium rosenbergii nodavirus (MrNV) and extra small virus (XSV), the pathogenic agents of white tail disease of Macrobrachium rosenbergii (De Man), by loopmediated isothermal amplification. J Fish Dis 29: 275-283.

33. Tsai SM, Chan KW, Hsu WL, Chang TJ, Wong ML, et al. (2009) Development of a loop-mediated isothermal amplification for rapid detection of orf virus. J Virol Methods 157: 200-204.

34. Varga A, James D (2006) Use of reverse transcription loop-mediated isotherma amplification for the detection of Plum pox virus. J Virol Methods 138: 184-190. 